\title{
The U.S. Role in the International System: A Prospective Study
}

\author{
Dr. Mohammad Youssef Daradkeh \\ Assistance Teacher \\ Al-Baeet Univercity \\ Jordan
}

\begin{abstract}
This study addresses the American role in the international system through the use of qualitative and quantitative methods to study the economic, social and military indicators within three levels of comparison: the degree of influence of international forces in different parts of the world, the relations between international powers and the degree of influence of military, political and economic factors where the researcher came to a conclusion that the influence of the American role increases with the increase of US control over the Middle East, East Asia, Latin America more than Russia, China and European Union. Moreover, the same influence would increase if the relations between the friendly relations between America, Japan, America and China became stronger, and the influence of the military and political factors in the international system on the economic factor of America's relative decline has increased.
\end{abstract}

Keyconcepts: US role, international system, military factor, areas of influence Economic factor, Foreign policy, Declince, Levels of comparison

\section{Introduction}

Upon the emergence of the United States as a dominant power following WWII, it adopted and enforced a trend towards control and intervention in international affairs and domination of global economy at the expense of the supporters of a policy of isolation and looking after internal affairs. "Political powers with conflicting standpoints have emerged between the supporters of isolation, managing internal affairs and not intervening in other countries' policies on the one hand, and the supporters of intervention in political life, international affairs and domination of global economy and directing it to the service of the US economy."

But an observation of the American foreign policy from the point of view of supporters of isolation reveals that this view was driven by factors including:

- Achieving the American economic and political growth away from the problems of the European continent, thus moving away from Europe's interests "due to the fact that achieving American interests was associated with moving away from Europe, so the United States only recently contributed to the evolution of international system" ${ }^{2}$.

- The US' abstinence from international affairs since its founding and its preoccupation with establishing its liberal political system to foster the concept of political citizenship had reinforced the political actors calling for a policy of isolation. The radical transformation in the development of the US foreign policy appeared towards the mid-20th century as one of the outcomes of the Second World War itself, and the emergence of communist power lead by the Soviet Union as the US's biggest rival. The factors that influenced the US foreign policy may be summarized as follows ${ }^{3}$ :

1. The growth of the financial and industrial powers of the United States.

2. The relative stability of the internal political system and the strong support of citizens for the American system of government, and their belief that it is a system that surpasses other regimes.

3. The technological revolution in communication, transportation and warfare.

4. The massive geographic size of the United States which made it a gateway to different civilizations on distant shores of the Atlantic and Pacific.

All this prompted the United States during the cold war to harness greater military capabilities and develop a programs of cooperation with neighboring States. Hence the document (NSC-68), published by the US Security Council in 1950, stated that the United States should take the lead in building a political and economic system for the free world.

\footnotetext{
${ }^{1}$ Qalaji, Q. (1992). America and the Hubris of Power.The Arab Writer. $1^{\text {st }} \quad$ Ed..P. 7.

2 Denny, B.; Abdul-Rahman, W (translator) (1991). Seeing American Foreign Policy Whole, Egypt: International Publishing House. ${ }^{3}$ Ibid.
} 
One of the outcomes of the second world war was a power vacuum in the continents of Asia and Europe, thus views on dealing with this void in political thought outside of the United States had arose. One of the outcomes of the second world war was a power vacuum in the continents of Asia and Europe, thus views on dealing with this void in political thought outside of the United States had arose.

- First, the US fills this void through its influence on both sides of the Eurasian continent in the framework of the security and military alliances.

- Second, the revival of powers that have long rivaled the Soviet Russian influence in the continents of Europe and Asia, with the revival of the Japanese military and economic power in Asia and rebuilding the German military force to be the nucleus of a military economic group in the face of the Soviet influence in Europe. According to the views of George Kennan, "the vision proposed by Kennan is to rebuild the traditional balance of power within the Eastern biosphere in which German and Japan play the main role in containing Soviet power with the help of the United States, without its direct military intervention. ${ }^{4}$

The relative decline in the United States' ability to control the international economy after the cold war during the 1990s resulted in the emergence of new thriving economic powers. This retreat, which traces its beginnings to the mid1970s has caused some analyses in international relations to indicate the type of role sharing between military power, represented by the United States and economic power represented by Japan and Germany into the Western Alliance; "this trend toward relying on the military dimension has led to a kind of implicit role sharing within the Western Alliance defense tasks entrusted to the United States as its key partners carry the economic burden for the maintenance of this system, whether in the form of an economic aid program in Third World countries, or carry the bulk of funding U.S. military operations." ${ }^{5}$

But this state of role sharing between the economic and military powers represented by Japan and Germany on the one hand, and the United States on the other in managing the international system, shall prevail, or that the path, as the researcher observes, shall take the following curve:

- The US economic crisis deepened at all levels and indicators.

- An increase in defense spending in the United States out of the overall GDP.

- The emergence of trends to form a nucleus of military defense in the Western Alliance away from the United States either in Europe or in Asia.

All these factors result in an imbalance in the equilibrium and task division between the economic and military levels of international powers, which is reflected on the effectiveness of the American role, causing a decline in its ability to lead international affairs within the international system.

\subsection{Research significance:}

1.Scientific importance: Scientific significance: To emphasize the heavy influence of the American role in the international system across three levels: the degree of influence of international powers in different regions of the world represented by Russia, China, Japan and the European Union, relations between powers of the aforementioned international powers, the degree of influence of economic factors and the international system's political future.

2.Scientific importance: Practical importance: streamlining decision making in the foreign policy of various states, as mentioned in the scientific significance.

\subsection{The main research problem and how to address it:}

The main problem of this study proceeds from the premise that "the weakness of the United States' economic strength components compared with other international forces will reduce the ability of the United States to exercise political influence in the international system."What follows then is a group of mechanisms that make the United States' behavior visible within the international system. These mechanisms are:

- Compensation for economic vulnerability by persuading international powers to increase their defense capabilities.

- An attitude of bargaining will prevail in its negotiation with the international powers.

- Increased use of power collectively in resolving international disputes.

To demonstrate and analyze this problem, the researcher will use a comparative method against Japan as a rising power in light of economic, military, cultural and social indicators, because measuring the ability of a state is only possible by comparison with another power, since power is relative.

\footnotetext{
${ }^{4}$ Haggag, K. (1997). Features of the American Strategy in the Next Century: International politics. Egypt: Al-Ahram Foundation. 127. P. 127.

${ }^{5}$ Ibid.,P. 69.
} 
Then, the researcher will arrive at a number of possibilities for the United States' role in the international system in light of the presumption of probable scenarios of improvement or decline in its relationships with international powers.

\subsection{Research hypotheses:}

1. The US role in the international system grows with the increase of its influence in the regions: the Middle East, Southeast Asia and Latin America.

2. The US role in the international system grows as the influence of friendly relations between the US and Japan, and the US and China increases.

3. The US role in the international system grows with and the influence if the military and political fact that increase and influence of the economic factor goes down.

\section{Indicators of American and Japanese power components:}

Two study frameworks lie under this section. First, a study at the level of international economy indicators; and secondly, a comparison between Japan and the United States economically, socially and militarily.

\subsection{Current international economy indicators:}

We can also include indicators of the status of the international economy with the following data ${ }^{6}$ :

1. The end of the era of steady exchange rates and the breakdown of the international monetary system after the United States abandoned the convertibility of the dollar into gold in 1971, and the beginning of the stage of floating, the chaos of the international monetary markets which caused disorder in the international economy transactions.

2. The growing form of speculation in the international capital markets through financial flows without a link to the processes of production, employment and investment.

3. Varying asymmetric growth relationships between leading industrial countries and increase of the relative weight of Western Europe and Japan in the global economy.

4. Worsening relations between deficit and surplus between industrial capitalist states on the one hand, and developing countries on the other, and also between the capitalist states themselves.

5. The increasing volume of global unemployment due to the dramatic technological revolution.

6. The imbalance between supply and demand in the international economy, thus increasing global supply over global demand.

These indicators will affect the economic mobility within the US economy as follows:

- Increasing the size of the trade deficit between the United States and the major capitalist powers.

- High volume of various types of unemployment in the United States.

- The devaluation of the dollar against other currencies in the international economy to identify production surplus.

- Increasing the penetration of the American market from other capitalist forces in various fields of industries such as cars, aircrafts.

\subsection{U.S. and Japanese economic indicators:}

The most important economic indicators are as follows then ${ }^{7}$ :

- Growth rate of US gross income: It is noted that the rate of growth in US gross income between the years 19601969 was equal to 4.05 , and then became 2.79 in 1970-1979, and 2.69 in 1980-1989. In 1991, the growth rate in the US gross income was -0.05 , indicating that it was steadily deteriorating.

- The status in the central production sectors between the United States and Japan is illustrated by the following table ${ }^{8}$ :

\begin{tabular}{|l|l|l|}
\hline Field & $\begin{array}{l}\text { American Center } \\
\mathbf{1 9 8 0 / 1 9 9 0}\end{array}$ & $\begin{array}{l}\text { Japanese Center } \\
\mathbf{1 9 8 0} / \mathbf{1 9 9 0}\end{array}$ \\
\hline Micro-electronics & $2 / 1$ & $1 / 2$ \\
\hline Computers & $1 / 1$ & $2 / 6$ \\
\hline Robots and machinery & $3 / 2$ & $1 / 3$ \\
\hline
\end{tabular}

${ }^{6}$ Zaki, R. (1997). The Political Economy of Unemployment: An analysis of the most serious problems of the contemporary capitalism. Kuwait: National Council for Culture, Arts and Literature.P. 53-55.

${ }^{7}$ Abdul-Hay, W. (1996). The Future Status of the United States on the Ladder of International Powers, International Politics.Egypt:AlAhram Foundation.P. 12 .

${ }^{8}$ Ibid. 
We notice by the previous table the speed in transformation in the Japanese center within these centers of production to be higher than that of the United States, where we notice its retreat to the second place in two areas of production listed in the previous table.

- The center of major economic institutions, we notice that the relative concentration of major economic institutions in Japan is increasing in the United States between 1970 and 1990. This is exemplified by the following table?:

\begin{tabular}{|l|l|l|l|l|}
\hline Economic foundation & Relative positioning in the United States & \multicolumn{2}{|c|}{ Relative positioning in Japan } \\
\hline $\begin{array}{l}\text { Giant corporations } \\
(100 \text { companies })\end{array}$ & $42 \%$ & $64 \%$ & $15 \%$ & $8 \%$ \\
\hline Grand Banks & $10 \%$ & $38 \%$ & $48 \%$ & $20 \%$ \\
\hline Service Companies & $10 \%$ & $40 \%$ & $70 \%$ & $20 \%$ \\
\hline
\end{tabular}

- The Federal deficit and national debt: the United States suffered from a federal deficit of $\$ 59.6$ billion, and national debt 914.3 billion dollars in 1960 and the amount of federal deficit became 300 billion and national debt $\$ 4$ trillion by the year 1990 .

We therefore notice a rapid increase in the growing federal deficit since the year 1960. These facts are a clear indication that the United States is turning into a partner, pursuing a policy of mutual benefits negotiated with partners in order to improve the competitiveness of its industry ${ }^{10}$. To face the deficit in the movement of these economic indicators, the United States pursued a selective foreign policy the primary objective of which is to achieve American interests based on economic security and increase market share and competing with it. "The major U.S. interest is to raise the standard of living of the American people, and secure a competitive American economy by opening markets to international trade $" 11$.

With the growing pressure of the American public in the trend towards internal economic problems limiting the ability of the United States to use military force in international affairs management, "the public opinion in America insists that it is impossible for the president to send U.S. military teams to South East Europe, where less than 50\% of all Americans supported air strikes on Serb positions, and six out of twelve people were the against sending U.S, troops." ${ }^{12}$ This was also reflected in the US-Iraq crisis with regards to the inspection regime. If we start from the fact that job creation for Americans is linked to economic growth, reflecting increased volume of exports to foreign markets, and disturbances in these markets reduce the capacity of these markets to absorb U.S. exports, it becomes clear that the U.S. economy's reliant on external markets, an extra $\$ 1$ billion in U.S. exports produces 20 thousand new jobs. And the emergence of vast markets in Central and Eastern Europe and South Africa and South America, East and Southeast Asia against American goods, services and investments "13.

\section{A. Social indicators of the United States and Japan:}

Perhaps one of the most important social indicators in Japanese-American situation is education.

The declining level of education in the U.S. is revealed by the following data ${ }^{14}$ :

- More than 15 percent of the American population is illiterate and about 30\% of elementary school students graduate and are almost illiterate.

- Highschool dropout at about 25\% of students in the United Standpoints compared to 6\% in Japan.

- IQ tests showed that the average Japanese student's intelligence was 117 points compared to 100 points for the American.

- The number of school days in the United States are 180 days for 220 days of Japanese student.

- The high crime rate in U.S. cities where crime has risen by about 560\% between 1960-1992, where 60 million Americans citizens are in possession of a gun and 120 million guns are used to kill 19000 people annually.

- A deepening tendency towards individualism and pursuit of material profit. This is revealed in job instability in American institutions in comparison with Japan.

\footnotetext{
${ }^{9}$ Ibid.,P. 14.

${ }^{10}$ Froehling, H. C. \& Rauch, A. M.. The GATT Agreement and the World Economy, Außenpolitik. 1. 94.

${ }^{11}$ De Castro, R. (1995). Changes in U.S. Post-Cold War Hagemony: The Case of the East Asian Pacific Region. Außenpolitik.

12 George Schild: America's Foreign Policy Progmation, Außenpolitik, 1, 1995, P.39.

13 Charles Weston: Key us Foreign Policy Interests. Außenpolitik, 1, 1997, P.53.

14 These indicators were collected from:

1. Demashqiyyeh, N. (1997).“American Hegemony Over the World: Until when?”.The Arab Scholar.

2. Abdul-Hay, W. (1996). The Future Status of the United States on the Ladder of International Powers, International Politics. Egypt. AlAhram Foundation, previous reference.P. 17-20.
} 
- The United States is ranked number 29th in terms of number of scientists, technicians and engineers to the total population as it has only 55 technical world per 1000 people compared to 317 scientists and technicians per 1000 people in Japan, and the average rate of scientists in Japan is 16 times the US average. ${ }^{15}$

\subsection{Military Indicators:}

Among the most important military indicators that can be addressed are:

1. The increase of volume of US military spending compared with the Japanese military spending, which leads to exhaustion of the United States from the inside, reached in 1980 about 130.2 billion dollars, 314 billion dollars in 1990 and declined to 250 billion dollars in 1995 with the presence of 374 military bases abroad

2. The military sector development accounted for $64 \%$ of the research and development (R\&D) expenditures, and the increase in the defense expenditures of the gross national product (GNP) from $21.2 \%$ in 1980 to $21.6 \%$ in 1992.

3. Increased weaponization of armed conflicts in the world. Out of 50 border or ethnic conflicts between 1993 and 1994, at least one party obtained weapons from the United States in 45 disputes for a percentage of $90 \%$.

The relative importance of the U.S. military force diminishes in the two following cases:

1. The European continent's tendency to build an independent European defense force.

2. The Asian continent, led by Japan or China, aims to form an independent Asian defense force, as if Japan is rearming itself.

We must say, however, that the United States is currently confident of its security excellence, and the US military forces continue to provide a relative effectiveness to the American foreign policy. The United States is the only country capable of managing wide-scale military operations effectively away from its borders. It is also the key security partner in many areas, providing a base for regional stability through mutual benefits of security partnerships. ${ }^{16}$

Overall, we can say that the American strategy contains many elements and foundations and principles upon which to build the U.S. military strategy for the next century and this includes ${ }^{17}$ :

- Optimal use of military force in terms of mission, size and quality of forces.

- Clear identification of vital interests in all fields.

- Specific criteria for the nature and dimensions of American intervention using all powers of the state.

- Providing maximum security protection for the European region.

- Maintaining Israel's security and military superiority in the Middle East.

- Development of defense and military investments.

- Preserving the leading global role of the United States.

- Confronting weapons proliferation.

Thus we can say that American military thinking is governed by two directions:

1. The United States to must carry the burden of security alone in the continents of Europe, Asia and later, Africa.

2. The United States should carry the security burden in alliance with other international powers in Europe, Asia and Africa.

It is clear that isolationism no longer exists in American military and foreign political planning. Everyone is "intrusive" at the global level, whether unilateral or otherwise. ${ }^{18}$

\section{The future of the American role in relation to international forces:}

We will address the future of the American role in its relationship with international powers in three domains of interaction and influence:

1. The degree of influence of the international forces in different regions of the world.

2. The degree of relationship between the different international powers.

3. The degree of influence of economic, military and political factors in guiding the movement of the international system.

\subsection{The degree of influence of the international forces in different regions of the world:}

\footnotetext{
${ }^{15}$ Abd-Allah, Abdul-Khaliq (1996),.The Current International System: Facts and illusions. Internation Politics.Egypt:Al-Ahram Foundation. 124, P. 45.

${ }^{16}$ Awni, M. (1997). The American Military Strategy and Its Position on American Foreign Policy. Internation Politics.Egypt:Al-Ahram Foundation.P. 96.

${ }^{17}$ Fat'hi, A. (1997). American Military Strategies for the Next Century. International Politics.Egypt:Al-Ahram Foundation. P. 193.

${ }^{18}$ Amin, S. x(1992). Militarism in the "New World Order": Unity.Rabat:National Council for Arabic Culture.P. 38.
} 


\begin{tabular}{|l|l|l|l|l|l|}
\hline Region & The United States & Russia & China & Japan & The European Union \\
\hline The Middle East & A & B & C & C & B \\
\hline East Asia & A & C & B & B & C \\
\hline Africa & B & C & C & C & A \\
\hline Latin America & A & C & C & C & C \\
\hline
\end{tabular}

\section{A: High degree of impact $\quad$ B: Medium degree of impact $\quad$ C: Weak degree of impact}

It appears from the table above that the United States in general remains a highly influential international power in three major areas that are the Middle East, East Asia, Latin America, followed by the European forces.

\subsection{Relations between the international powers}

\begin{tabular}{|l|l|l|l|l|}
\hline No. & The United States and China & The United States and Japan & Japan and China & Russia and China \\
\hline 1 & 1 & 1 & 1 & 1 \\
\hline 2 & Zero & 1 & Zero & Zero \\
\hline 3 & 1 & Zero & Zero & 1 \\
\hline 4 & Zero & Zero & 1 & 1 \\
\hline 5 & 1 & Zero & Zero & Zero \\
\hline
\end{tabular}

Meaning of no 1: A friendly relationship.

Meaning of zero: An aggressive relationship.

By observing the situations in this table, we see that the U.S. role is diminishing in the fifth and fourth situation where the U.S. relations are hostile with both China and Japan in parallel with friendly relations between Japan and China, and between China and Russia. It is clear that the best cases for the United States are the second and fifth cases where the friendly relations between the United States and Japan (situation n. 2) or the United States and China (situation no. 1).

Therefore, the researcher believes that American relations are affected by the existence of:

1.Friendly relations in Asia between China and Japan.

2. Friendly relations in Europe between the European Union and Russia.

3.3. The degree of influence of the military, political and economic factors in the future direction of the international system

\begin{tabular}{|l|l|l|l|}
\hline No. & The economic factor. & The political factor & The military factor \\
\hline 1 & b & a & A \\
\hline 2 & a & b & B \\
\hline 3 & a & b \\
\hline 4 & a & a & A \\
\hline 5 & b & b & A \\
\hline
\end{tabular}

A: high impact degree in directing the center of the international system.

b: Less degree of impact in directing the center of the international system.

Upon reviewing the five cases, we note that the American role remains very effective in the first cases, a situation in which the United States prefers to remain the strongest politically and militarily with little degree of impact of the economic factor in international affairs as a result of economic weakness, as the researcher made clear through economic indicators. Afterwards, there is the case in favor of the fourth status of the prevalence and dominance of the military factor, but the worst case of its global role is the second situation where the economic factor prevails to guide the movement of the international system in exchange for the decline of the political and military factors.

\section{Conclusion}

The researcher concludes that the American role tends to diminish relatively in directing the movement of the international system if the following conditions in the interactions between international powers from another perspective coincide:

1. The emergence of strong relationships and interconnectedness between Japan and China in the Asian continent or strong ties and interconnectedness between Western and Eastern European countries on the European continent.

2. Accompanying the aforementioned emergence is the prevalence of the economic factor in international affairs management and the dynamics of the international system.

3. Continued priority of directing American foreign policy for security and military considerations and the concomitant increase in defense expenditure. 
4. The emergence of new sources of international conflict poses a major threat to international stability for the United States to be able to adjust and determine easily and substantially.

\section{References}

\subsection{Arabic references:}

Abdul-Hay, W. (1996). The Future Status of the United States on the Ladder of International Powers. International Politics. Egypt: Al-Ahram Foundation.

Abd-Allah, Abdul-Khaliq (1996). The Current International System: Facts and illusions. International politics. Egypt: Al-Ahram Foundation.124.

Amin, S. (1992). Militarism in the "New World Order": Unity, National Council for Arabic Culture, Rabat, Morocco.

Awni, M. (1997). The American Military Strategy and Its Position on American Foreign Policy, Internation Politics. Egypt: Al-Ahram Foundation.

Demashqiyyeh, N. (1997), American Hegemony Over the World: Until when?, The Arab Scholar.

Denny, B.; Abdul-Rahman, W (translator) (1991). Seeing American Foreign Policy Whole.Egypt: International Publishing House.

Fat'hi, A. (1997), U.S. Military Strategies for the Next Century, International Politics, Egypt,Al-Ahram Foundation.

Haggag, K. (1997), Features of the American Strategy in the Next Century: International politics, Egypt,Al-Ahram Foundation.

Qalaji, Q. (1992). The Hubris of Power.Dar Al-Kitab Al-Arabi. ${ }^{\text {st }}$ Ed.

Zaki, R. (1997). The Political Economy of Unemployment: An analysis of the most serious problems of the contemporary capitalism. Kuwait: National Council for Culture, Arts and Literature.

\subsection{Foreign periodicals:}

De Castro, R. (1995). Changes in U.S. Post-Cold War Hagemony: The Case of the East Asian Pacific Region. Außenpolitik.

Froehling, H. C. \& Rauch, A. M. (1994). The GATT Agreement and the World Economy. Außenpolitik.

Schild, G. (1995). America's Foreign Policy. Außenpolitik.

Weston, C. (1997). Key us Foreign Policy Interests. Außenpolitik. 